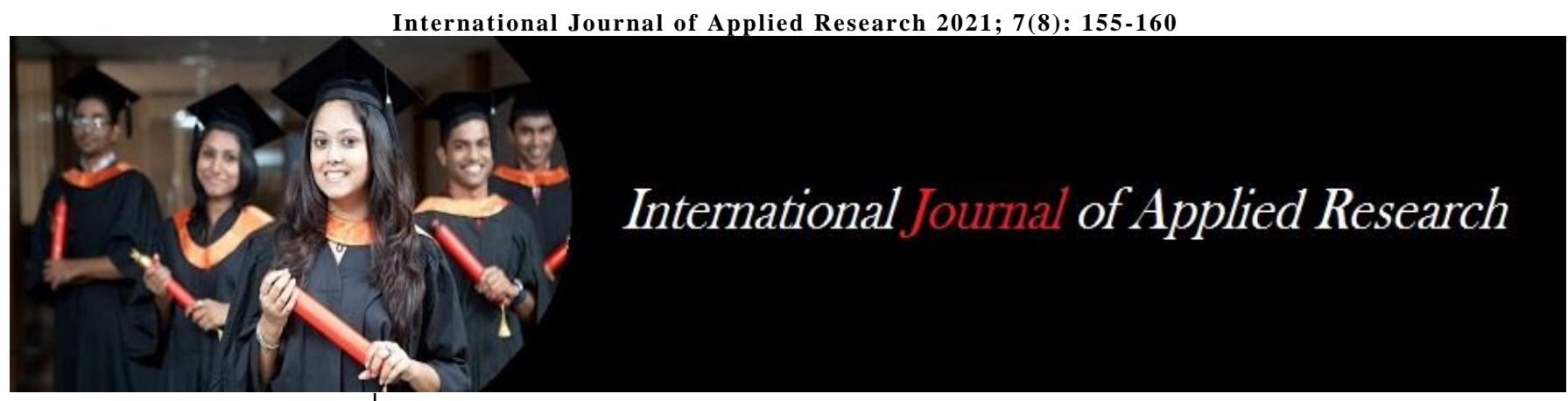

ISSN Print: 2394-7500

ISSN Online: 2394-5869

Impact Factor: 8.4

IJAR 2021; 7(8): 155-160

www.allresearchjournal.com

Received: 16-06-2021

Accepted: 20-07-2021

Surbhi Maheshwari

P.G. Scholar, Department of

Rasa Shastra \& Bhaishajya

Kalpana, Govt. P.G

Ayurvedic College \& Hospital,

Varanasi, Uttar Pradesh, India

\section{Richa Pathak}

Assistant Professor,

Department of Rasa Shastra \&

Bhaishajya Kalpana, Govt.

P.G. Ayurvedic College \&

Hospital, Varanasi, Uttar

Pradesh, India

Ankit Kumar Gupta

Associate Professor,

Department of Rasa Shastra \&

Bhaishajya Kalpana, Govt.

P.G. Ayurvedic College \&

Hospital, Varanasi, Uttar

Pradesh, India

Sanjay Kumar Pandey

Professor \& Head, Department of Rasa Shastra \& Bhaishajya

Kalpana, Govt. P.G.

Ayurvedic College \& Hospital,

Varanasi, Uttar Pradesh, India

Corresponding Author: Surbhi Maheshwari P.G. Scholar, Department of Rasa Shastra \& Bhaishajya Kalpana, Govt. P.G.

Ayurvedic College \& Hospital,

Varanasi, Uttar Pradesh, India

\section{Taila murchchhana with respect to comparative physico-chemical analysis of plain sarshapa taila and murchchhita sarshapa taila}

\author{
Surbhi Maheshwari, Richa Pathak, Ankit Kumar Gupta and Sanjay \\ Kumar Pandey
}

DOI: https://doi.org/10.22271/allresearch.2021.v7.i8b.8840

\section{Abstract}

Sneha Kalpana (medicated Taila and Ghrita) is one of the important dosage form among Ayurvedic medicament. It is used as both externally and internally. While preparing Sneha Kalpana first of all Sneha should undergo one particular Samskara called Sneha Murchchhana and it is used for Amadoshaharatwa, removal of bad odor, imparting color and increasing potency of the drug. Sarshapa Taila Murchchhana was done as mentioned in Bhaishajyaratnavali. Analysis on modern parameters of plain and Murchchhita Sarshapa Taila was done and comparison of various parameters on quality assessment were done. By Murchchhana process Sarshapa Taila converted into dark red colour from light yellow and get good order from pungent sulphurous odour. Physico-chemical parameters were applied for assessing the prepared formulation. The physico-chemical analysis showed slightly increased weight per millilitre $(\mathrm{g})(0.9076)$. The moisture content $(\% \mathrm{w} / \mathrm{w})$ slightly decreased $(0.09)$ which shows decrease in rancidity. The viscosity $(\mathrm{cpc})$ decreased considerably from 122 to 60 which shows increased rate of absorption. The acid value decreased (0.8047) which shows decrease in rancidity. We conclude that Murchchhita Sarshapa Taila is better than plain Sarshapa Taila for medicated oil preparations.

Keywords: sneha kalpana, ayurvedic medicament, samskara, sarshapa taila murchchhana, plain sarshapa taila

\section{Introduction}

Ayurveda has given the greatest emphasis to comprehensive knowledge of drugs including identification, procurement, processing, preservation and dispensing of prepared drug under a broad heading known as Bhaishajya Kalpana. The term Bhaishajya Kalpana is formed by the combination of words 'Bhaishajya' and 'Kalpana'. Bhaishajya - that which wins the disease or beneficial in Chikitsa or material presented for the treatment through the Bhishaka is called Bhaishajya, and it is also called 'Aushadha' (medicine) ${ }^{[1-3]}$. Kalpana - it is the process or the method employed for pharmaceutical processings ${ }^{[4]}$. Kalpana is said- Yojana (planning) to convert a material into useful form to the body ${ }^{[5,6]}$. Thus 'Bhaishajya Kalpana' is the science which deals in detail about the preparation of different medicines by using some raw material according to physicians requirements.

This science explains various methods of processing a drug in order to make the drug- More palatable, rich with potency, pleasing with good odor, colour etc, and long lasting or improve the self life of the prepration. The basic processing techniques of Bhaishajya Kalpana are elaborately explained in Samhitas. They were called the Panchavidha Kashaya Kalpana. Swarasa, Kalka, Kwatha, Hima, Phanta ${ }^{[7]}$. These have been derived from five Kashaya yoni expect Lavana Rasa. All Kalpanas are mainly based on water contents or water soluble part. Since they have less shelf life so to prepare the formulations which can be preserved for long time and can be administered conveniently- Churna, Vati, Sneha, Sandhana Kalpana etc. were introduced. Sneha Kalpana is well known among these. Sneha preparations have better pharmacokinetic action in comparison to other dosage forms because of the lipoid nature of the biomembranes, as lipid soluble substances readily permeate into the cells. 
Introduction of Sneha Kalpana into Ayurvedic pharmaceutics may be the result of the above mentioned facts. The rationality behind taking oil as a base is presumably to extract lipid-soluble active fractions from the ingredients into the oil and even this formulation holds its properties for longer period when compared to primary preparations. Sneha Kalpana is again of two types depending upo base material i.e. Ghrita and Taila Kalpana. Taila Kalpana have been used abundantly due to its use for all four modes of drug administrations like Pana, Abhyanga, Nasya, Basti and through all the bodily routes of drug administration. While preparing Sneha Kalpana first of all Sneha should undergo one particular Samskara called Sneha Murchchhana. It is applicable for both Ghrita and Taila. Sneha Murchchhana is not described in ancient books Charaka Samhita, Sushrut Samhita, Astanga samgraha, Astanga hridaya. Murchchhana process is firstly mentioned in Sharngdhara Samhita commentary by Kashiram's Gudhartha-Dipika ${ }^{[8]}$. Yogatarangini Brihatyogatarangini, Yogratnakar and Bhaishajyaratnavali also delt with concept of Sneha Murchchhana. Bhaishajyaratnavali delt details of the Murchchhana of different oils (Tila Taila, Sarshapa Taila, Erand Taila) and Ghrita with specific herbal drugs.
The main aim of Sneha Murchchhana is to remove the Durgandha, Amadosa, and Ugrata etc. bad characters of crude form of Sneha. Eventhough the word Ama in the context to Taila is not clearly defined, probably the water content existing in oil or the factor which inhibit the absorption (internal and external) of oil can be correlated. By doing Murchchhana, Sneha will get good smell and colour, apart from these, because of Murchchhana, Sneha will get such a capability to receive more active principle while the preparation of Sneha Paka and also by doing Murchchhana, the virya (potency) of the Sneha is enhanced. Because of Murchchhana, Sneha will get the active principles of Murchchhana Dravyas too.

\section{Material and Methods}

Murchchhana is a special pharmaceutical procedure before subjecting the drugs to SnehaPaka. Sarshapa Taila being best Kushthahara was selected as Sneha Dravya ${ }^{[9]}$.

\subsection{Pharmaceutical Study}

3 batches of Murchchhita Sarshapa Taila were prepared for the study as references of Bhaishajyaratnavali ${ }^{[10]}$.

\section{Ingredients}

Table 1: Showing the Ingredients and Their Ratios for Sarshapa Taila Murchchhana by Bhaishajyaratnavali ${ }^{[10]}$

\begin{tabular}{|c|c|c|c|c|c|}
\hline S. No. & Ingredie-NTS & Latin Name & Family & Part Used & Quantity \\
\hline & Kalka & & & & \\
\hline 1. & Amalaki & Phyllanthus emblica & Euphorbiaceae & Pericarp & $1 \mathrm{Karsh}(12 \mathrm{gm})$ \\
\hline 2. & Haridra & Curcuma longa & Zingiberacea & Rhizome & $1 \mathrm{Karsh}(12 \mathrm{gm})$ \\
\hline 3. & Musta & Cyprus rotandus & Cypraceae & Tuber & $1 \mathrm{Karsh}(12 \mathrm{gm})$ \\
\hline 4. & Bilva & Aegel marmelos & Rutaceae & Unripe Fruit & $1 \mathrm{Karsh}(12 \mathrm{gm})$ \\
\hline 5. & Dadima & Punica granatum & Punicaceae & Seeds & $1 \mathrm{Karsh}(12 \mathrm{gm})$ \\
\hline 6. & Nagakeshara & Mesua ferrea & Calophyllaceae & Stamens & $1 \mathrm{Karsh}(12 \mathrm{gm})$ \\
\hline 7. & Krisna Jiraka & Carum carvi & Umbelliferae & Fruit & $1 \mathrm{Karsh}(12 \mathrm{gm})$ \\
\hline 8. & Hribera & Pavonia odorata & Malvaceae & Root & $1 \mathrm{Karsh}(12 \mathrm{gm})$ \\
\hline 9. & Nalika & Cinnamomum zeylanicum & Lauraceae & Inner stem bark & $1 \mathrm{Karsh}(12 \mathrm{gm})$ \\
\hline 10. & Bibhitaka & Terminalia bellirica & Combretaceae & Pericarp & $1 \mathrm{Karsh}(12 \mathrm{gm})$ \\
\hline 11. & Manjishtha & Rubia cordifolia & Rubiaceae & Root & 2 Pala $(96 \mathrm{gm})$ \\
\hline & Sneha & & & & \\
\hline & Sarshapa Taila & Brassica campestris & Brassicaceae & Seed oil & 1 Prastha (768ml.) \\
\hline & Drava & & & & - \\
\hline & Water & - & - & & $1 \mathrm{Adhaka} \mathrm{(3.72} \mathrm{litre)}$ \\
\hline
\end{tabular}

Table 2: Showing Ingredients and Their Weights used for Sarshapa Taila Murchchhana.

\begin{tabular}{|c|c|c|}
\hline S. No. & Ingredients & Weight \\
\hline 1 & Sarshapa Taila & 4 Prastha $(3072 \mathrm{ml})(2646 \mathrm{gm})$ \\
\hline 2 & $\begin{array}{c}\text { Kalka - [Amalaki, Haridra, Musta, Bilva, Dadima, Nagakeshara, Krisna jiraka, } \\
\text { Hribera Nalika, Bibhitaka,] } \\
\text { [ Manjishtha] }\end{array}$ & $\begin{array}{c}72 \text { Karsh }(864 \mathrm{gm}) \\
{[\text { Each } 4 \text { Karsh }(48 \mathrm{gm})]} \\
{[8 \text { Pala }(384 \mathrm{gm})]}\end{array}$ \\
\hline 3 & ( & $\begin{array}{c}4 \text { Aadhaka }(12288 \mathrm{ml}) \\
(11736 \mathrm{gm})\end{array}$ \\
\hline
\end{tabular}

*1 Karsa = 12gm In the case of liquid, the metric equivalents would be the corresponding litre and milliliter ${ }^{[11]}$

So, 1 Prastha $=64$ Karsa $=768 \mathrm{ml}$

*The conversion of $\mathrm{ml}$ into gm in this table is done by weighing on the weigh machine.

\section{Equipments}

Mortar \& pestle, Mixer-Grinder, Sieve, Heating device gas burner with LPG cylinder, Aluminium Vessel Diameter-46.5cm, Depth-26cm, wt $-6.8 \mathrm{~kg}$, and Capacity 50 lit., Cotton cloth, Measuring cylinder, stainless steel ladle, Thermometer.

\section{Procedure}

All the Kalka Dravyas were made into coarse powder form (Yavakut Churna) and Kalka was prepared by soaking in water that was $2500 \mathrm{ml}$ and left undisturbed overnight (about $18 \mathrm{hrs}$ ).

On next morning Sarshapa Taila was taken in a aluminium vessel and heated over Madhyama Agni till complete evaporation of moisture content, and the temperature was around $164^{\circ} \mathrm{C}$. The Kalka was added to the Taila after slight cooling, and the temperature was around $95^{\circ} \mathrm{C}$.

After adding Kalka, water was added and heated it with intermediate stirring. Heating process was carried out till Sneha Siddhi Lakshana appeared, then vessel was taken out 
from the fire and Taila was filtered through clean cloth in its hot stage. Murchchhita Sneha was store in a container after cooling.

\section{Precautions}

- Fresh Sarshapa Taila should be taken.

- The vessel used for the process should be clean and of adequate size, inorder to avoid spilling of Taila due to excess foaming during Murchchhana process.

- Kalka should be made with coarse powder and soaked into water overnight to avoid the sticking of Kalka to the vessel

- When froth appears in the Taila, the temp was maintained to protect the Taila coming out from vessel.

- Continuous stirring was carried out to avoid the sticking of Kalka especially in last stage.

\section{Observations during Murchchhana}

- Initiation of process crackle sound was heard in Sarshapa Taila.

- Appearance of fumes and eye irritation get started due to fumes.

- Specific smell of Sarshapa Taila.

- When Taila get moisture free then the fumes comes out abundantly and the colour of Taila slightly changes but unable to differentiate clearly.
- Froth appears when Kalka was added.

- After adding Kalka and water colour of Taila gets converted into reddish orange colour, and after complete Paka it converts into dark red colour.

- Bubble and bubble sound appears during Sneha Paka.

- Smell of Kalka Dravya appears during heating process.

- At Mridu Paka stage absence of crackling sound when oil was sprinkled on the fire but crackling sound was present when Kalka Dravya was sprinkled on the fire.

- Phena appeared at Mridu Paka stage and disappear at Madhyama Paka stage.

- At Madhyama Paka stage absence of crackling sound when oil and Kalka particles were sprinkled on the fire.

\subsection{Analytical Study}

Analysis of Sarshapa Taila and Murchchhita Sarshapa Taila was done as per "General Guidelines for Drug Development of Ayurvedic Formulations", Volume - 1, Central Council for Research in Ayurvedic Sciences, Ministry of Ayush, Govt. of India, New Delhi, $1^{\text {st }}$ edition - 2018. Physico chemical analysis of the samples were carried out at Multani Pharmaceuticals Limited (Analytical division), Haridwar, Uttarakhand and $\mathrm{pH}$ of the samples was carried out at laboratory of Deptt. Of Rasa Shastra and Bhaishajya Kalpana, BHU, Varanasi.

\section{Observation and Result 3.1 Pharmaceutical Study}

Table 3: Observations with Temperature $\left({ }^{\circ} \mathrm{C}\right)$ During Sarshapa Taila Murchchhana

\begin{tabular}{|c|c|c|c|c|}
\hline Observations & $\mathbf{1}^{\text {st }}$ Batch & $2^{\text {nd }}$ Batch & $3^{\text {rd }}$ Batch & Average \\
\hline Initial temp. of Sarshapa Taila & 34.5 & 36 & 34 & 34.8 \\
\hline Temp. when Taila get moisture free & 164 & 172 & 155 & 163.7 \\
\hline Temp. at the time of Kalka add & 95 & 100 & 110 & 101.7 \\
\hline Temp. after adding Kalka and at the time of water add & 76 & 58 & 60 & 64.7 \\
\hline Temp. after adding water & 57 & 40 & 41 & 46 \\
\hline Temp. at which boiling of Taila start & 96 & 94 & 94 & 94.7 \\
\hline Temp. after one hour of starting of Taila boiling & 99 & 97 & 97.6 & 97.9 \\
\hline Temp. at the time of Phenodgama & 98 & 96.9 & 93 & 96 \\
\hline Temp. at the time of Mridu Paka stage & 94 & 96.9 & 93 & 94.6 \\
\hline Temp. at the time of Madhyama Paka stage & 95.5 & 98 & 93 & 95.5 \\
\hline Temp. at the time of filtration & 90 & 91 & 85 & 88.7 \\
\hline
\end{tabular}

Table 4: Duration of Sarshapa Taila Murchchhana

\begin{tabular}{|c|c|c|c|c|}
\hline Observation & $\mathbf{1}^{\text {st }}$ Batch & $2^{\text {nd }}$ Batch & $3^{\text {rd }}$ Batch & Average \\
\hline Total duration to obtain moisture free condition (in min.) & 48 & 35 & 42 & 42 \\
\hline Time of Kalka added (in min.) & 73 & 60 & 68 & 67 \\
\hline Time of water added (in min.) & 78 & 65 & 72 & 72 \\
\hline Time of starting Taila boiling (in min.) & 115 & 103 & 105 & 108 \\
\hline Time of Phenodgama & 11 hrs. $25 \mathrm{~min}$. & $13 \mathrm{hrs} 8 \mathrm{~min}$. & $12 \mathrm{hrs} 30 \mathrm{~min}$. & $12 \mathrm{hrs} 21 \mathrm{~min}$. \\
\hline Duration of Mridu Paka stage & $11 \mathrm{hrs} 40 \mathrm{~min}$. & 13 hrs $8 \mathrm{~min}$. & $12 \mathrm{hrs} 30 \mathrm{~min}$. & 12 hrs $26 \mathrm{~min}$. \\
\hline Duration of Madhyama Paka stage & $14 \mathrm{hrs} 17 \mathrm{~min}$. & $15 \mathrm{hrs} 10 \mathrm{~min}$. & $14 \mathrm{hrs} 45 \mathrm{~min}$. & $14 \mathrm{hrs} 44 \mathrm{~min}$. \\
\hline Total time required for Taila Murchchhana & $14 \mathrm{hrs} 17 \mathrm{~min}$. & $15 \mathrm{hrs} 10 \mathrm{~min}$. & $14 \mathrm{hrs} 45 \mathrm{~min}$. & $14 \mathrm{hrs} 44 \mathrm{~min}$. \\
\hline Total time required for Taila Murchchhana ( in days) & 3 & 3 & 3 & 3 \\
\hline
\end{tabular}

Table 5: Sneha Siddhi Lakshana of Taila Murchchhana

\begin{tabular}{|c|c|c|}
\hline S. No. & Sneha Siddhi Lakshan & \\
\hline 1 & Sanyav eve niryase & -ve \\
\hline 2 & Madhye darvi vimunchati & $+\mathrm{ve}$ \\
\hline 3 & Varti formation & $+\mathrm{ve}$ \\
\hline 4 & Shabda hino Agni nikshipta & $+\mathrm{ve}$ \\
\hline 5 & Phenodgama & $+\mathrm{ve}$ \\
\hline
\end{tabular}


Table 6: Showing the Result Obtained During Preparation of Sarshapa Taila Murchchhana

\begin{tabular}{|c|c|c|c|c|}
\hline Result & $\mathbf{1}^{\text {st }}$ Batch & $2^{\text {nd }}$ Batch & $3^{\text {rd }}$ Batch & Average \\
\hline Initial quantity of Sarshapa Taila (in ml.) & 3072 & 3072 & 3072 & 3072 \\
\hline Initial quantity of Sarshapa Taila (in gm.) & 2646 & 2646 & 2646 & 2646 \\
\hline Obtained quantity of Murchchhita Sarshapa Taila (in ml.) & 2702.15 & 1840 & 1915 & 2152.38 \\
\hline Obtained quantity of Murchchhita Sarshapa Taila (in gm.) & 2329.39 & 1558.18 & 1587.8 & 1825.12 \\
\hline Loss of Taila (in ml.) & 369.85 & 1232 & 1157 & 919.62 \\
\hline Loss of Taila (in gm.) & 316.61 & 1087.82 & 1058.2 & 820.88 \\
\hline$\%$ of gain in volume & 87.96 & 59.90 & 62.34 & 70.07 \\
\hline$\%$ of gain in weight & 88.03 & 58.89 & 60 & 68.97 \\
\hline$\%$ loss in volume & 12.04 & 40.10 & 37.66 & 29.93 \\
\hline$\%$ loss in weight & 11.97 & 41.11 & 40 & 31.03 \\
\hline Initial quantity of Kalka (in gm.) & 864 & 864 & 864 & 864 \\
\hline Obtained quantity of Kalka (in gm.) & 2638.8 & 2113.3 & 2266.2 & 2339.43 \\
\hline Colour of Kalka after filteration & Dark brown & Dark brown & Dark brown & Dark brown \\
\hline
\end{tabular}

*The conversion of $\mathrm{ml}$ into $\mathrm{gm}$ in this table is done by weighing on the weigh machine.

\subsection{Analytical Study}

Table 7: Showing Organoleptic Characters of Sarshapa Taila and Murchchhita Sarshapa Taila

\begin{tabular}{|c|c|c|c|c|c|}
\hline Sample & Colour & Taste & Odour & Consistency & Texture \\
\hline Sarshapa Taila & Light yellow & Katu, Tikta & Pungent Sulph-urous odour & Liquid & Oily \\
\hline Murchchhita Sarshapa Taila & Dark reddish & Tikta, Kashaya & Murchchhana Dravyas odour & Liquid & Oily \\
\hline
\end{tabular}

Table 8: Showing Different Physico - Chemical Parameters and Their Result of Sarshapa Taila and Murchchhita Sarshapa Taila

\begin{tabular}{|c|c|c|c|}
\hline S. No. & Parameters & Sarshapa Taila & Murchchhita Sarshapa Taila \\
\hline 1 & Weight $/ \mathrm{ml}(\mathrm{g})$ at $40^{\circ} \mathrm{C}$ & 0.9051 & 0.9076 \\
\hline 2 & $\mathrm{pH}$ value & 4.84 & 3.65 \\
\hline 3 & Moisture content $(\% \mathrm{w} / \mathrm{w})$ & 0.13 & 0.09 \\
\hline 4 & Refractive index at $40^{\circ} \mathrm{C}$ & 1.4673 & 1.4694 \\
\hline 5 & Viscosity $(\mathrm{cpc})($ Spindle No. 64$)$ & 122 & 60 \\
\hline 6 & Iodine value & 106.22 & 108.31 \\
\hline 7 & Saponification value & 195.80 & 193.54 \\
\hline 8 & Unsaponifiable matter & 0.81 & 0.34 \\
\hline 9 & Acid value & 2.72 & 0.8047 \\
\hline 10 & Peroxide value & 11.45 & 11.6159 \\
\hline 11 & Mineral oil test & Absent & Absent \\
\hline
\end{tabular}

Table 9: Showing Microbial Count of Sarshapa Taila and Murchchhita Sarshapa Taila

\begin{tabular}{|c|c|c|c|}
\hline Sample & Total Viable Aerobic Count & Total Fungal Count & Enterobacteriaceae Presence \\
\hline Sarshapa Taila & $<10$ & $<10$ & Absent \\
\hline Murchchhita Sarshapa Taila & 10 & $<10$ & Absent \\
\hline
\end{tabular}

\section{Discussion}

As the present article is a preliminary study it can be concluded that Pharmaceutical study of Sarshapa Taila Murchchhana took $14 \mathrm{hrs} .44 \mathrm{~min}$. in completion for 4 Prastha (3072 ml) amount of Sarshapa Taila. At Madhyama Paka stage absence of crackling sound when oil and Kalka particles were sprinkled on the fire. It shows the absence of water content in Murchchhita Sarshapa Taila. Average quantity of Taila obtained in volume was $70.07 \%$ and average loss in volume was found to be $29.93 \%$.

Analytical study show that after Murchchhana process the colour of Sarshapa Taila was converted in dark red from light yellow because of Manjishtha that was used as Kalka Dravya in Murchchhana process. Taste of Sarshapa Taila was Katu \& Tikta, which was converted in Tikta \& Kashaya after Murchchhana process. Pungent sulphurous odour of Sarshapa Taila was converted in Murchchhana Dravyas odour in Murchchhita Sarshapa Taila.

In physico-chemical characters the weight per millilitre (g) slightly increased after the process of Murchchhana which may be due to the addition of some active bioconstituents from the herbs used for Murchchhana. Murchchhita Sarshapa Taila is more acidic than plain Sarshapa Taila, this indicates that the drugs used in Murchchhana are more acidic in nature e.g. Amalaki. After Murchchhana process, moisture content became less $(0.09 \% \mathrm{w} / \mathrm{w})$ that is negligible that show Murchchhita Sarshapa Taila is good with respect to rancidity. The refractive index after Murchchhana slightly increased which may be due to colouration and phytoconstituents. Because of Murchchhana process viscosity of Sarshapa Taila decreases. If the viscosity of the liquid preparation is decreased, the rate of absorption is increased. The iodine value increased a bit and the saponification value decreased a bit after Murchchhana process. The unsaponifiable matter after Murchchhana decreased when compared to Taila which indicates the process of refining. A high acid value in the oil may leads to early rancidity of the oils. The acid value decreased after Murchchhana process. There was slightly increase in the peroxide value after Murchchhana and this indicated that there is no more difference in the stability due to Murchchhana process. Mineral oil in Sarshapa Taila and 
Murchchhita Sarshapa Taila was absent. Total viable aerobic count was slightly increased after Murchchhana process, but it is much less than the maximum acceptable count of total aerobic microbe $\left(10^{2} \mathrm{CFU} / \mathrm{g}\right.$ or CFU/ml $=200$ -according to The International Pharmacopoeia). This may be due to improper hygiene during the preparation or packing of drug.

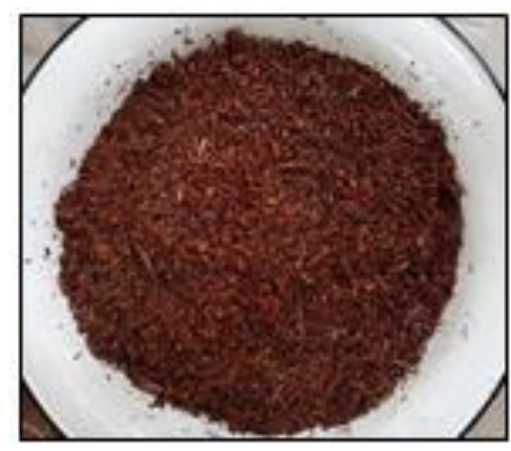

Kalka Dravya

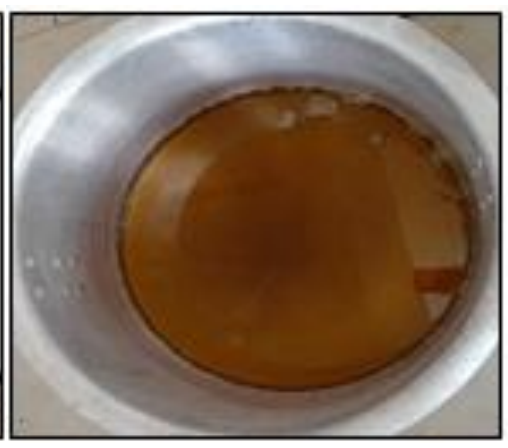

Sarshapa Taila

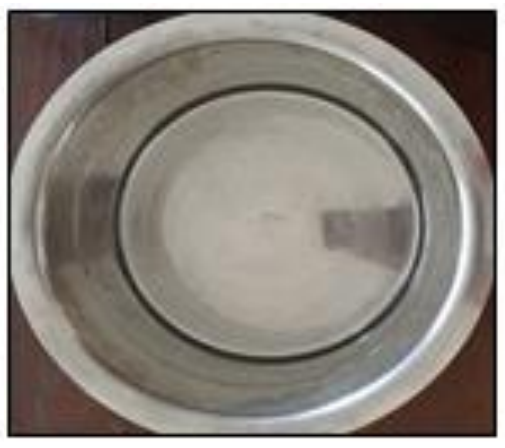

Water

Fig 1: Ingredients of Sarshapa Taila Murchchhana

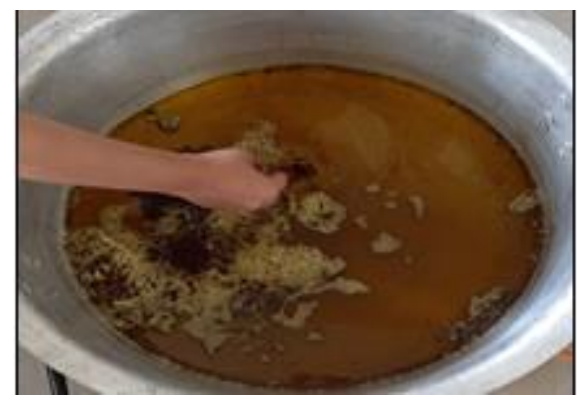

Fig 2: Adding Kalka

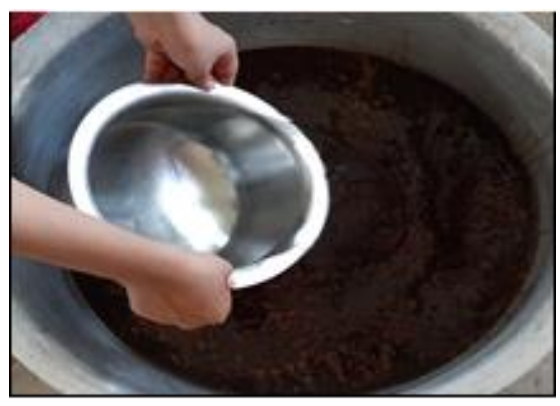

Fig 3: Adding Water

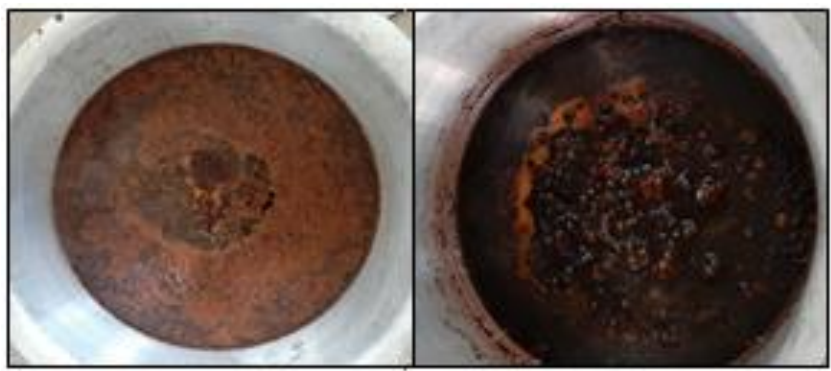

Fig 4: Boiling of Taila

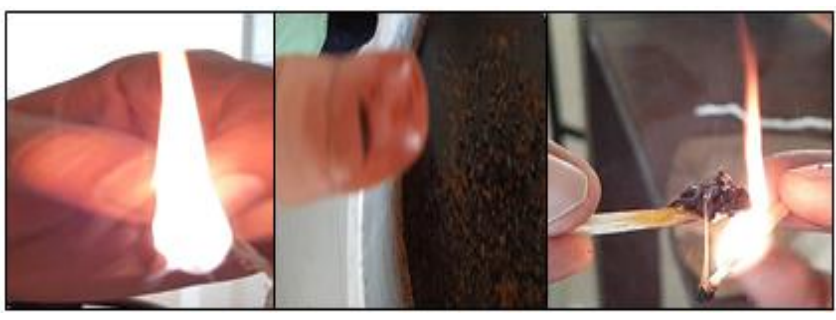

Fig 5: Sneha Siddhi Lakshana

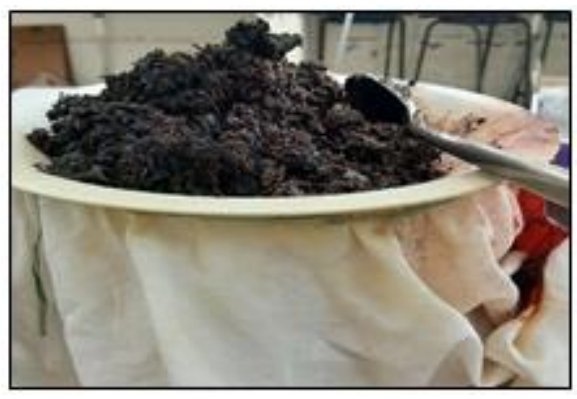

Fig 6: Filtration

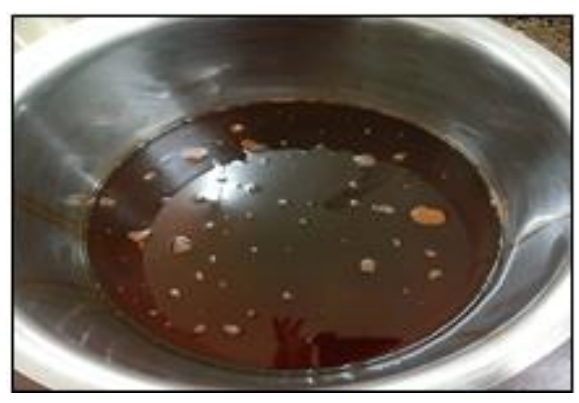

Fig 7: Prepared Murchchhita Sarshapa Taila

\section{Conclusion}

From the above review, it has been concluded that after Murchchhana process, the Sarshapa Taila gets all characters that described in Ayurvedic texts. By doing Murchchhana, Sneha will get good smell and colour. Because of Murchchhana, Sneha will get the active principles of Murchchhana Dravyas too. The physico-chemical analysis showed weight per millilitre (g) (0.9076), $\mathrm{pH}$ value (3.65), moisture content $(\% \mathrm{w} / \mathrm{w})(0.09)$, refractive index (1.4694), viscosity (cpc) (60), iodine value (106.22), saponification value (193.54), unsaponifiable matter (0.34), acid value (0.8047), peroxide value (11.6159) and mineral oil test (absent). These parameters showed that Murchchhita Sarshapa Taila is better than plain Sarshapa Taila for medicated oil preparations.

\section{Acknowledgement}

I acknowledge Deptt. Of Rasa Shastra \& Bhaishajya Kalpana, Govt. PG Ayurvedic College \& Hospital, Varanasi for allowing me to work and perform this study. I would also like to express my sincere thanks to Multani 
Pharmaceuticals Limited (Analytical division), Haridwar, Uttarakhand for carrying out the analytical studies on time. I am also thankful to Deptt. Of Rasa Shastra \& Bhaishajya Kalpana, I.M.S, B.H.U. specially Prof. Anand Chaudhary Sir, Deptt. Of Rasa Shastra \& Bhaishajya Kalpana, I.M.S, B.H.U. and Mr. Ram Ashish, non teaching staff of Deptt. Of Rasa Shastra \& Bhaishajya Kalpana, I.M.S, B.H.U. for supporting in analytical study.

\section{References}

1. Raja Radha Kanta Deva. Shabda-Kalpadrum. Edn 3, Part 3, Chowkhamba Sanskrit Series, Varanasi 1967, 543.

2. Vraddha Jivaka. Kasyapa Samhita, Vidyotini hindi commentary by Sri Satyapala Bhisagacharya. Reprint Edn, Chaukhambha Sanskrit Sansthan, Varanasi 2009, 242.

3. Pt. Sarngadharacharya. Sarngadhara-Samhita, commentary of Adhamalla's Dipika and Kasirama's Gudhartha-Dipika. Edn 3, Chaukhambha orientalia, Varanasi 1983, 16.

4. Raja Radha Kanta Deva, Shabda-Kalpadrum, Edn 3, Part 2, Chowkhamba Sanskrit Series, Varanasi 1967, 64.

5. Vagbhata, Astangahrdayam, Sarvangasundara commentary of Arunadatta and Ayurvedarasayana commentary of Hemadri. Edn 7, Chaukhambha orientalia, Varanasi 1982, 735.

6. Agnivesa. Caraka Samhita, Ayurveda-Dipika commentary of Cakrapanidatta and Vidyotini hindi commentary by Pt. Kasinatha Sastri. Edn 6, Part 1, Chaukhambha Sanskrit Sansthan, Varanasi 2000, 57.

7. Agnivesa. Caraka Samhita, Vidyotini hindi commentary by Pt. Kasinatha Sastri \& Dr. Gorakha Natha Chaturvedi. Part 1, Chaukhambha Bharati Academy, Varanasi 2018, 67.

8. Pt. Sarngadharacharya. Sarngadhara-Samhita, commentary of Adhamalla's Dipika and Kasirama's Gudhartha-Dipika., Chaukhambha orientalia, Varanasi 1983, 215.

9. Agnivesa. Caraka Samhita, Vidyotini hindi commentary by Pt. Kasinatha Sastri \& Dr. Gorakha Natha Chaturvedi. Reprint Edn, Part 2, Chaukhambha Bharati Academy, Varanasi 2009, 267.

10. Sri Govind Das. Bhaisajyaratnavali, Vidyotini hindi commentary by Shri Kaviraja Ambikadatta Shastri Ayurvedacharya. Reprint Edn, Chaukhambha Prakashan, Varanasi 2018, 186.

11. The Ayurvedic Formulary of India. Edn 1, Part 3, Deptt. Of AYUSH, Ministry of Health and Family Welfare, New Delhi 2011, 705. 